training is best for the scientific worker who wishes to enter industry, were summarized by Dr. Oplin, director of research at Kendall Mills, Boston. His summary has been taken up by Science Service, Washington, D.C., and circulated. His principal conclusions are: "Industries need physicists trained in the fields of optics, magnetism and acoustics", and "too little emphasis is placed on these fields in academic training" as "the best known scientists are working on the problems of cosmic rays, atomic disintegration and transmutation" and "students naturally look up to them for guidance". "Some training in engineering courses is advocated for future industrial physicists. Industry finds it better and easier to use a student trained adequately in physics and have him in the plant attain his additional engineering knowledge than to try to give the engineering student the additional knowledge of physics".

\section{R.R.S. Discovery II Survey Party}

CONSIDERABLE concern was caused by the announcement on January 18 from the commanding officer of the R.R.S. Discovery II, that a survey party which had been landed on King George Island, South Shetlands, was missing. Early on the following day, however, the reassuring message was received that the party had been located and had returned to the ship. The Discovery Committee states that the party consisted of : Lieut. R. Walker, R.N.R., chief officer; Dr. J. R. Strong, ship's surgeon ; Dr. F. D. Ommanney, scientific officer; Mr. R. G. Gourlay, third engineer ; Mr. J. Matheson, boatswain's mate; and Mr. J. Dobson, A.B.

\section{Bureau of Human Heredity}

ONE activity contemplated in setting up the Bureau for Human Heredity is the organization of information service for research workers in the subject. The value of such a plan has been demonstrated in the information service already established for workers on Drosophila, etc. Workers are requested, to address to the Bureau a short paragraph describing the work on which they are engaged. These notices will be multiplied and circulated to all those cooperating. In the first instance, this bulletin will be issued every twelve months. Later supplementary bulletins will be issued more frequently. Those using this service are asked to subscribe $5 s$. Communications should be addressed to the Hon. General Secretary, Bureau of Human Heredity, 115 Gower Street, London, W.C.1.

\section{Federal Council on Scientific Management}

AN important step forward in the co-ordination of the varied activities of the many societies connected in some way or other with the several phases of scientific management was taken on January 12, when a British Management Council was formed. After the highly successful sixth International Congress for Scientific Management, held in London during July 1935, a committee was set up under the chairmanship of Dr. E. F. Armstrong both to take all necessary action to ensure the proper representation of Great Britain at the next Congress, to take place in the United States in 1938, and to examine the factors involved in the formation of a national scientific management organization. A scheme of federation has been produced by this committee, and after discussion has met with provisional acceptance from the greater number of the associations concerned, numbering some thirty in all. The objects of the new Federal Council are: "To ascertain and represent both nationally and internationally the views of those bodies concerned in Management in Great Britain, and in particular as its immediate object to enter into relations and to co-operate with similar bodies in other countries, and to act as the representative of its Constituent Members in International Congresses and other activities concerned with Management." Lord Leverhulme has been elected as its first chairman, Dr. E. F. Armstrong as vice-chairman, Mr. G. R. Freeman as treasurer, and Mr. U. Baliol Scott as secretary. The new body is assured of the support and co-operation of the Federation of British Industries. It has an important function to fill and may be expected in time to exert a pronounced influence on the development of the functional management movement in Great Britain.

\section{Botanical Society of America}

Ar its thirty-first annual meeting at Atlantic City, New Jersey on December 20-31, the Botanical Society of America elected the following botanists to be corresponding members: Dr. N. I. Vavilov, director of the State Institute for Experimental Agronomy, Leningrad; Dr. Agnes Arber, sometime fellow of Newnham College, Cambridge; and Dr. Lorenzo R. Parodi, professor of botany in the University of Buenos Aires. The following officers of the Society for 1937 were also elected : President, Prof. Edmund W. Sinnott, Barnard College, Columbia University, New York City; Vice-President, Prof. Loren C. Petry, Cornell University, Ithaca, N.Y.; Secretary, Prof. George S. Avery, jun., Connecticut College, New London, Conn.; Treasurer, Dr. F. E. Denny, Boyce Thompson Institute for Plant Research, Yonkers, N.Y. A new Section for Paleobotany was also organized with the following officers: Chairman, Prof. A. C. Noé, University of Chicargo ; Secretary, W. C. Darrah, Harvard University.

\section{International Congress of Agriculture}

THE seventeenth International Congress of Agriculture will be held at The Hague on June 16-23, 1937, under the patronage of the Queen of the Netherlands. The work of the Congress is divided among eight sections. Three are economic in character, and at The Hague will discuss the means which have been taken to deal with the depression in the agriculture of the Netherlands, the organization of the world butter market, the provision of credit to agriculture, the relation between State planning and agricultural co-operation, the effect on agriculture of the development of artificial wools, cottons and other products. Sections dealing with the technical and 
scientific aspects of agriculture will discuss the vernalization of crops, a limitation in the varieties of plants in cultivation and the protection of producers of selected seeds, artificial fertilization in the im. provement of livestock, animal nutrition and other subjects. Social and educational questions will include the teaching of agricultural economics, broadcasting in the service of agriculture and health and hygien $\theta$ in the rural home, a subject to which the National Federation of Women's Institutes (England) will make the principal contribution. Further particulars may be obtained from the Secretary, British Corresponding Committee, International Congress of Agriculture, 10 Doughty Street, London, W.C.l.

\section{An International Exhibition of Photography}

LNDER the chairmanship of Gustave Fassin, of the Bausch and Lomb Scientific Bureau, Rochester, New York, a committee has been appointed to secure and arrange exhibits for the International Exhibition of Applied and Scientific Photography to be held in the Rundell Memorial Building at Rochester, New York, in March, under the auspices of the local section of the Photographic Society of America. This new and beautiful civic building has exceptional facilities for showing both pictures and apparatus. Men of science working in any of the following fields are invited to send exhibits to the Secretary. Mr. C. B. Neblette, Rochester Athenæum and Mechanics Institute, Rochester, New York: astronomy, meteorology, light-sensitive substances; photomicrography, microphotography, metallography; X-ray spectrography ; cosmic ray photography and theoretical physics; press photography; high-speed photography; technique of colour photography; photography by invisible radiation; aerial photography.

\section{Awards of the Geological Society}

The Geological Society has made the following awards: Wollaston Medal to Prof. Waldemar Lindgren of the Massachusetts Institute of Techno$\operatorname{logy}$, for his researches concerning the mineral structure of the earth, and especially concerning the problems of mesasomatism, contact ore deposits and the application of physical chemistry to ore deposition; Murchison Medal to Dr. L. J. Spencer, in recognition of the value of his original contributions to mineralogical science and of his services to the publication of mineralogical literature; Lyell Medal to Mr. L. Richardson, for his contributions to the geology of the Jurassic rocks of Great Britain; Bigsby Medal to Prof. C. E. Tilley, in recognition of the value of his researches in petrological science, especially in the petrology of the metamorphic rocks; Wollaston Fund to Dr. D. Parkinson; Murchison Fund to Mr. S. H. Straw; a moiety of the Lyell Fund to Mr. J. F. Jackson; another moiety of the Lyell Fund to Miss M. E. Tomlinson.

\section{Announcements}

DR. E. J. BUTLER, secretary of the Agricultural Research Council; Dr. J. B. Conant, president of Harvard University ; and Lord Hailey, director of the African Research Survey, have been elected members of the Athenæum under the provisions of Rule II of the Club, which empowers the annual election by the committee of a certain number of persons of distinguished eminence in science, literature, the arts, or for public service.

Mr. J. RAmsвotrom, keeper of botany at the British Museum (Natural History), and a secretary to the Linnean Society of London, who is known for his mycological researches, has been elected an honorary member of the Quekett Microscopical Club.

Mr. Richmond T. Zock, of the U.S. Weather Bureau, has been elected a foreign member of the Royal Meteorological Society.

The annual general meeting of the Association of Technical Institutions will be held in the Carpenters' Hall, Throgmorton Avenue, London, E.C.2, on February 26-27. On February 26, at 10.45 a.m., the incoming president, the Right Hon. Lord Kennet, will deliver the presidential address. Further information can be obtained from Dr. H. Schofield, Loughborough College, Loughborough, Leicestershire.

THE fourth International Grassland Congress will be held in Great Britain under the presidency of Prof. R. G. Stapledon on July 8-23. The Congress will meet first at Oxford and will then proceed to various places of topical interest including Leicester, Birmingham, Cirencester, Hereford, Aberystwyth, Newcastle and Edinburgh. Further information can be obtained from the Joint Secretaries, Agricultural Buildings, Aberystwyth.

THE Associated Grocery Manufacturers Association of America at the annual banquet on December 1 presented Dr. George R. Minot of Boston with the annual award for research in the field of health leading to the prevention of disease and the advancement of health. The presentation address was made by Dr. Morris Fishbein, editor of the Journal of the American Medical Association.

Dr. JoHN HowARD Northrop, of the Rockefeller Institute for Medical Research, Princeton, N.J., has been awarded the Charles Frederick Chandler Medal of Columbia University in recognition of his fundamental discoveries concerning bacteria, the constitution of protein and the chemistry of digestion. The medal was founded in 1910 in honour of Prof. Chandler, who taught at Columbia University and was a pioneer in industrial chemistry.

Dr. Davide Grordano, president of the Italian Society of the History of Medicine and Natural Sciences ; Dr. Bernhard Peyer, professor of palæonto. logy at Zurich; and Dr. Brouwer, professor of neuropathology at Amsterdam, have been elected members of the Leopold Caroline German Academy of Natural Philosophy at Halle. 